\author{
Dr. sc. Mato Arlović \\ sudac Ustavnog suda Republike Hrvatske
}

\title{
VLADA DEMOKRATSKOG JEDINSTVA KOALICIJSKI ODGOVOR NA VELIKOSRPSKU AGRESIJU
}

\author{
$U D K: 342(497.5)$ \\ DOI: $10.31141 /$ zrpfa.2020.57.136.453 \\ Izvorni znanstveni rad \\ Primljeno: 1. studenog 2019.
}

Rad se bavi političkim i ustavnopravnim pitanjima koja su prethodila osnivanju Vlade demokratskog jedinstva. Napose, pitanjima koja su vezana uz agresorski rat protiv Republike Hrvatske. U radu se razmatraju mogući razlozi zbog čega se za Vladu demokratskog jedinstva izbjegava koristiti (u raspravi o njoj) njezino obilježje da je koalicijska vlada, iako ona to, nesporno, jest - po načinu svoga nastajanja, nadležnosti i samog djelovanja. Pored toga, ukazuje se na značaj i učinke Vlade demokratskog jedinstva sa ciljem smirivanja i stabiliziranja tadašnjeg kaotičnog političkog stanja u Republici Hrvatskoj, radi jačanja jedinstva i sloge, te u svrhu odlučnog opredjeljenja hrvatskog naroda u političkom smislu za uspostavu ravnopravne zajednice državljana koji će braniti i obraniti Republiku Hrvatsku i njezine građane, te joj osigurati slobodu, puni teritorijalni integritet i suverenitet. Jedan od temeljnih ciljeva bio je međunarodno priznanje u okviru granica koje je Hrvatska imala kao Socijalistička Republika Hrvatska. Prethodno navedena pitanja kojima ću se baviti u ovom radu, primarno ću obraditi s ustavnopravnog aspekta, ali i s aspekta međunarodnog prava.

Ključne riječi: koalicija, Vlada demokratskog jedinstva, Domovinski rat, ustavnost i zakonitost, velikosrpska agresija, velikosrpska secesionistička politika, saoizacija

\section{UVOD}

Formiranje Vlade demokratskog jedinstva od iznimnog je značaja u ostvarivanju samostalne, suverene, teritorijalno cjelovite i demokratske Republike Hrvatske, zatim u organiziranju stanovništva u njezinoj obrani te zbrinjavanju izbjeglih i prognanih građana, njihova povratka u mjesta svog prebivališta, poštovanja ustavnopravnog poretka, zaštite ljudskih i manjinskih prava, te sloboda bez diskriminacije po bilo kojoj osnovi itd. Unatoč takvu značaju i posebnom, istaknutom mjestu u modernoj povijesti Republike Hrvatske, ipak postoje još uvijek neka pitanja i proturječja koja traže i s pravom očekuju naše odgovore. Među njima su pitanja: u političkopravnom smislu, što je to Vlada demokratskog jedinstva, koalicijska vlada i kakva koalicija i/ili Vlada nacionalnog jedinstva, s obzirom na to da je tako neki istaknuti pojedinci nazivaju, zatim tko je inicirao i predložio njezino formiranje, zašto je ili iz kojih 
razloga formirana; je li bila nužna i opravdana u demokratskom društvu i je li svojim radom opravdala svoje formiranje i egzistenciju itd.

Oko ovih pitanja i dilema postoje različiti pristupi u iznalaženju i davanju odgovora. Najčešće se pitanja i odgovori temelje na sjećanju i empiriji živih sudionika tog vremena, uz manje i/ili više upotrebljavane, relevantne, dostupne dokumentacije. Ovim radom i sam ću ponuditi neke odgovore na postavljena pitanja analizirajući okolnosti i događaje iz vremena formiranja Vlade demokratskog jedinstva, te relevantne dostupne dokumente.

Cjelokupnu obradu raspoložive osnove za izradu ovog rada obavit ću primjenom znanstveno-stručnih metoda, primarno s ustavno-pravnog, a donekle i s političkopravnog aspekta. No, da bih mogao pristupiti tom poslu, prije svega smatram nužnim odrediti se prema pitanju što smatram, ili još bolje, što prihvaćam kao pojam koalicijske vlade.

\section{O POJMOVIMA KOALICIJA I KOALICIJSKE VLADE}

Koalicija kao pojam etimološki svoje uporište i izvorište ima u latinskoj riječi coalescere što znači ujediniti se, odnosno srasti. U najširem značenju radi se o pojmu kojim se označava savez konkretnih organizacija u svrhu ostvarivanja određenog zajednički definiranog interesa i/ili cilja, sklopljenog na određeni rok. Odnosi se na vojni ili politički savez, odnosno između država ili političkih stranaka zbog zajedničkog djelovanja radi ostvarivanja zajedničkih interesa ili nekog zajedničkog cilja.

U teorijsku i praktičnu upotrebu u društvenim znanostima ušao je 1792. kada je riječju koalicija imenovan savez Austro-Ugarske i Pruske protiv revolucionarne Francuske.

Najčešće se koristi u političko-pravnim odnosima. Na razini međunarodnopravnih odnosa u koalicijske saveze ulaze države (dvije ili više) da bi ostvarile zajedničke ciljeve i/ili interese, ili kako bi otklonile prijetnje koje mogu ugroziti ili onemogućiti njihove interese i ciljeve.

U političkim odnosima pojmom koalicija označava se savez političkih stranaka sklopljen prije ili nakon provedenih izbora za parlamentarni saziv, u pravilu, u parlamentarnim demokratskim sustavima, s ciljem da članice koalicije lakše ostvaruju vlast kako bi stvorile političke pretpostavke za "uvećavanje političke dobiti i zajedničko ostvarenje određenih političkih ciljeva".

Političke koalicije parlamentarnih stranaka političari i političke teorije počeli su opravdavati početkom šezdesetih godina prošlog stoljeća, polazeći od temeljne postavke da je sudjelovanje u vladi glavni cilj političkih stranaka u parlamentarnoj demokraciji. "Ako nijedna stranka nema natpolovičnu većinu mjesta u parlamentu

1 Kasapović M.; “Izborni leksikon”, Politička kultura, Zagreb, 2003., str. 187. 
i ne može sama sastaviti vladu, stranke se udružuju kako bi stekle potrebnu većinu za sastavljanje vlade."2

Koalicijski savezi političkih stranaka mogu biti predizborni i postizborni. Predizborni savezi nastaju između političkih stranaka koje smatraju da će kao koalicija sinergijski postići veću političku dobit (veći broj glasova) kod birača nego što bi to u izborima ostvarile samostalno, za svoje programe i kandidate koji se biraju. Postizborna je koalicija usmjerena za stvaranje parlamentarne većine koja formira zajedničku koalicijsku vladu radi ostvarivanja zajedničkih interesa i ciljeva stranaka koje su ušle u koaliciju. ${ }^{3}$

Posebni oblik koalicije jest onaj koji nastupa iz viših razloga zbog zaštite i ostvarivanja nacionalnih i/ili državnih interesa i ciljeva. Radi se, u pravilu, o slučajevima kad se formiraju tzv. velike koalicije. ${ }^{4}$ Velike koalicije $^{5}$ najčešće se osnivaju u slučajevima ekonomskih kriza, velikih elementarnih razaranja, izvanrednog stanja uslijed ratne prijetnje i/ili ratnih stanja. Zapravo se radi o takvim okolnostima i društvenim zbivanjima u kojima društvena zajednica očekuje od političkih elita i njihovih stranaka upravo takvu koaliciju koja će postići i osigurati nacionalno jedinstvo u ostvarivanju i/ili zaštiti nacionalnih interesa, pa i u slučajevima kada se mora postići konsenzus oko teških, moguće i nepopularnih mjera. ${ }^{6}$

Bitna karakteristika velikih koalicija ogleda se u činjenici da u njoj sudjeluju političke (najjače u parlamentu) stranke (dvije ili više) koje su ideološko-politički suprotstavljene, a u parlamentu predstavljaju tradicionalnije izborne suparnike. Ovisno o dobrima i vrednotama, koje su ugrožene i koje treba zaštititi, i/ili o kvaliteti i značaju zajedničkih interesa i ciljeva važnih za parlamentarne stranke i društvo u cjelini, velike koalicije ne samo da mogu obuhvatiti sve parlamentarne stranke, već mogu uključiti kako izvanparlamentarne stranke tako i pojedince koji svojim znanjima, ugledom u društvu i djelovanjem mogu doprinijeti ostvarivanju zajedničkih interesa i ciljeva zbog kojih je osnovana velika koalicija. Kod stvaranja koalicija "preporučuje se poštovanje načela izborne responzivnosti, prema kojem u novoj koalicijskoj vladi ne bi trebale sudjelovati stranke koje su pretrpjele pad potpore birača u usporedbi s prethodnim izborima"?

Prihvaćeni model koaliranja od strane političkih partija zastupljenih u predstavničkom tijelu (parlamentu) u koje su izabrani njihovi kandidati često puta

2 Ibidem.

3 Ibidem (vidjeti pobliže noticu "koalicijska vlada"), str. 190.

4 Vidjeti o pojmu "velika koalicija" istoimenu noticu na https://hr.m.wikipedia.org >wiki.

5 Lj. Antić s pravom navodi da "Velika koalicija kao i svaka politička koncentracija ima nedostatke i prednosti. Nedostatak je demokratski deficit do kojeg dolazi zbog nedostatka kontrole izvršne vlasti. Prednost je pak izbjegavanje svih onih slabosti koje su karakterizirale dosadašnje višestranačke koalicijske vlade u kojima je svatko vukao na svoju stranu", vidjeti njegov rad: "Traži li Hrvatska nacionalni konsenzus", na: http://www.matica.hr/vijenac/492/trazi-li-hrvatska-nacionalni-konsenzus; posjet stranici 2. listopada 2019.

6 Pobliže vidjeti noticu "koalicija" u Politička enciklopedija, Savremena administracija, Beograd, 1975., str. 437.

7 Kasapović M., o. c., str. 189. 
određuje ne samo tip, već i ime koalicijske vlade. Tako npr. koalicija koja ima potporu većine u parlamentu, ali sve stranke parlamenta koje je podržavaju ne žele sudjelovati u vladi, naziva se manjinska koalicija, a i vlada se naziva manjinskom. Ta je koalicija, odnosno njena vlada, "općenito nestabilnija od većinske. Za razliku od manjinske koalicije i njezine manjinske vlade, većinska koalicija i njezina vlada imaju podršku i povjerenje većine i iznad nje članova parlamenta te dvije ili više parlamentarnih stranaka čiji članovi u parlamentu podržavaju i daju povjerenje većinskoj koalicijskoj vladi. Posebni oblik koalicijske vlade je onaj koji proizlazi iz koncentracione koalicije“ ${ }^{8}$ Radi se o koalicijama koje obuhvaćaju sve parlamentarne stranke, a nastaju u periodima nacionalne opasnosti, agresije na državu, rata, velikih elementarnih stradanja, epidemija i slično. Ove koalicije često puta nose ime koalicije demokratskog i/ili nacionalnog jedinstva, a vlade koje one formiraju imaju ime po nazivlju same koalicije.

Za takve je koalicijske vlade koje su rezultat dogovora (svih uključivo i najvećih) stranaka u parlamentu pa su po prirodi stvari velika koalicija, ispravnije upotrebljavati naziv Vlada demokratskog jedinstva. Prije svega zbog toga što su oni izraz dogovora političkih stranaka i njihovih izabranih kandidata u parlamentu, dakle u sustavima parlamentarne - narodne demokracije posredno izabranih nositelja vlasti, a ne neposrednih nositelja vlasti, odnosno primjerice samog naroda kao nositelja vlasti. No, ukoliko, i kada se takve vlade zbog njihovih zadaća i značaja za ostvarivanje i zaštitu nacionalne samobitnosti putem realiziranja političkih i općedruštvenih interesa i ciljeva nacionalnog značaja nazivaju i vlade nacionalnog jedinstva, onda je kod upotrebe ovog pojma potrebno imati u vidu tumačenje da nacionalno ne označava etničku pripadnost vlade. Naime, pojam nacionalno treba tumačiti činjenicom da se radi o vladi u kojoj su dogovorom parlamentarnih stranaka izabrani građani, dakle predstavnici npr. konstitutivnog naroda i drugih etničkih manjinskih zajednica, te da su oni članovi društvene i državne zajednice kao njezini slobodni i ravnopravni državljani. ${ }^{9}$ Zbog toga su u multietničkim društvima takve vlade u pravilu sastavljene od članova koji pripadaju različitim entitetima, ${ }^{10} \mathrm{~s}$ jedne strane, a s druge strane mogu, ali ne moraju biti članovi stranaka koje formiraju vladu.

8 Profesor Antić navodi svoju podjelu mogućih naziva za vlade koje nastaju koncentracijom svih ili većine parlamentarnih stranaka te piše:

"- ako se stvori nova vlada koncentracijom svih ili velike većine parlamentarnih stranaka te izvan parlamentarnih skupina pa i istaknutih pojedinaca. U tom slučaju govori se o nacionalnoj koncentraciji;

- ako se pak osnuje vlada na nešto užoj osnovici, pretežno iz parlamentarnih stranaka, obično se govori o vladi nacionalnog jedinstva, a u najtežim krizama ili ratnim stanjima o vladi nacionalnog spasa,

- jedna od inačica takve vlade je tzv. velika koalicija, koju čine dvije najjače političke stranke;

Vlada nacionalnog jedinstva pod nazivom Vlada demokratskog jedinstva djelovala je u uvjetima Domovinskog rata 1991/1992.", o. c.

9 U Republici Hrvatskoj takvo tumačenje proizlazi iz supstancijalnog sadržaja članka 1. stavka 2. Ustava "Narodne novine" broj 85/2010. Treba napomenuti da se navedena odredba hrvatskog Ustava kroz sve dosadašnje njegove promjene nije mijenjala i dopunjavala. Ona je ostala ista.

10 Sama Vlada demokratskog jedinstva Republike Hrvatske, neovisno o tome što je formirana $u$ ratnim uvjetima, po svom sastavu nije bila jednonacionalna. 
Vlada demokratskog jedinstva Hrvatske, o kojoj je riječ u ovom radu, jedan je od mogućih primjera vlada velikih koalicija, koju u javnom diskursu nazivaju i Vladom nacionalnog jedinstva. I to primarno zbog njezina značaja i doprinosa u zaštiti hrvatskih nacionalnih političkih interesa i ciljeva u Domovinskim ratu. Tako se pod nazivom Vlada nacionalnog jedinstva oslovljava i objašnjava III. Vlada demokratskog jedinstva Hrvatske na samom portalu Vlade Republike Hrvatske. ${ }^{11}$ Nadalje, umjesto službenog imena Vlada demokratskog jedinstva, ime Vlada nacionalnog jedinstva često upotrebljavaju mediji i njihovi portali, ${ }^{12}$ te nositelji ili ex nositelji javnih funkcija, pisci i znanstvenici. ${ }^{13}$

Međutim, i kada to čine, oni ovaj naziv upotrebljavaju kao istoznačnicu, neovisno o tome u kojoj se mjeri ta dva naziva u svom sadržaju podudaraju.

Za razliku od koalicijskih vlada, postoje homogene vlade koje formira samo jedna stranka koja je dobila izbore i ima potrebnu većinu u parlamentu za potporu izglasavanja povjerenja "svojoj" vladi. Homogene vlade često se formiraju u političkim sustavima u kojima je, u pravilu, jedna od stranaka pobjednik i ima većinu u parlamentu te može sama formirati vladu. Prilika je ukazati i na posebni tip vlade koju nazivamo činovničkim vladom. Ona bi po prirodi stvari trebala biti neutralna jer se formira na izvanstranačkoj osnovi. Karakteristična je za prijelazne periode ili za razdoblja u kojima je potrebno obaviti određeni, konkretni zadatak, u pravilu od državnog interesa. ${ }^{14}$

U nastavku rada bavit ću se konkretnom koalicijskom vladom koja je formirana u Republici Hrvatskoj 1991. godine.

\section{OKOLNOSTI, VRIJEME I RAZLOZI FORMIRANJA VLADE DEMOKRATSKOG JEDINSTVA}

\section{O OKOLNOSTIMA FORMIRANJA VLADE DEMOKRATSKOG JEDINSTVA}

Nakon provedenih prvih višestranačkih demokratskih izbora 1990., Hrvatska demokratska zajednica usvojila je relativnu većinu glasova izbornog tijela, ali je

11 Vidjeti na: https://vlada.gov.hr/prethodne-vlade-11348/11348. posjet 3. listopada 2019.

12 Vidjeti npr. sljedeće adrese: https://www.tportal.hr/vijesti/clanak/ovo-su-clanovi-ratne-vlade, ili članak intervjua autora Körbler J. u Glasu Istre od 29. srpnja 2019. s Franjom Gregurićem, predsjednikom Vlade demokratskog jedinstva itd.

13 Npr. Franjo Gregurić, predsjednik Vlade demokratskog jedinstva, u intervjuu navedenom u prethodnoj fusnoti, zatim Zdravko Tomac, sveučilišni profesor i jedan od potpredsjednika Vlade demokratskog jedinstva; vidjeti njegovu knjigu "Iza zatvorenih vrata - Tako se stvarala hrvatska država", Organizator, Zagreb, 1992., itd.

14 O tipovima koalicijskih vlada vidjeti: a) noticu "koalicija" kod Kasapović M., o. c., str. 187-189, i b) noticu "vlada" u Politička enciklopedija, o. c., str. 1143. 
zbog izbornih pravila u Hrvatskom saboru ostvarila apsolutnu većinu mandata. ${ }^{15}$ Takva stranačka većina u parlamentu toj je stranci omogućavala formirati homogenu vladu za vrijeme trajanja mandata prvog saziva Hrvatskog sabora. ${ }^{16}$ Tako je i postupala u formiranju I. i II. Vlade Republike Hrvatske. ${ }^{17}$ Međutim, unatoč apsolutnoj većini mandata vladajuće stranke, došlo je tijekom ljeta 1991. do formiranja Vlade demokratskog jedinstva Republike Hrvatske. Očigledno je da do njezina formiranja nije došlo iz altruističkih pobuda i na njima zasnovanih razloga većinske stranke - HDZ-a. Nema dvojbe da razloge i opravdanja za formiranje Vlade demokratskog jedinstva treba tražiti u društvenim okolnostima. Razlozi i opravdanja za to se mogu naći u društvenom i političkom realnom životu, a ne u altruizmu vladajuće stranke koja u parlamentu ima apsolutnu većinu od ukupnog broja parlamentaraca - zastupnika. Tim više što su ideološko-političke razlike između većinske pobjedničke stranke (HDZ-a) i najjače (najbrojnije po zastupnicima) opozicijske stranke Socijaldemokratske partije Hrvatske (dalje: SDPH) bile oprečne. ${ }^{18}$ Prema tome sasvim je izvjesno da se na osnovi ideološkopolitičkih opredjeljenja i programskih ciljeva između glavne pozicijske i glavne opozicijske stranke nije mogla postići zajednička osnova za formiranje vlade koja bi bila rezultat velike koalicije.

Osnovu za veliku koaliciju i na njoj formiranoj koalicijskoj Vladi demokratskog jedinstva valja tražiti u zahtjevu ostvarivanja nacionalnih i državotvornih interesa, obrani samobitnosti i sloboda hrvatskog naroda i svih njezinih građana, te njezina teritorijalnog integriteta i ustavnopravnog i državnog suvereniteta u nametnutom joj agresorskom ratu. To je bila odlučujuća točka koja je motivirala sve stranke zastupljene u Hrvatskom saboru da uđu u veliku koaliciju i na njezinu programu formiraju Vladu demokratskog jedinstva Republike Hrvatske. Prema tome, za izlučenje bitnih razloga koji su doveli do formiranja Vlade demokratskog jedinstva potrebno je sagledati vrijeme i okolnosti u kojima je ona nastala, te dominantne društveno-političke odnose koji su tada egzistirali u Hrvatskoj.

15 Kasapović M., “Demokratska konsolidacija i izborna politika u Hrvatskoj 1990.-2000.”, u Zborniku radova, (ur.) Kasapović M., Hrvatska politika 1990.-2000., Hrvatska politologija, Fakultet političkih znanosti, Sveučilište Zagreb, 2001., str. 21.

16 Prvi saziv Hrvatskog sabora obuhvaća mandat u vremenu od svog konstituiranja 30. svibnja 1990. do 7. rujna 1992., kada je konstituiran njegov II. saziv.

17 Nakon konstituiranja I. saziva Hrvatskog sabora, prvu Vladu Republike Hrvatske vodio je njezin predsjednik Stjepan Mesić, drugu u istom sazivu Sabora vodio je Josip Manolić, a III. koalicijsku vladu, Vladu demokratskog jedinstva, do kraja tog saziva Sabora, odnosno do imenovanja i potvrđivanja IV. Vlade, vodio je njezin predsjednik dr. Franjo Gregurić.

18 Navedenu tezu smatram nepotrebnim posebice elaborirati. Naime, u Hrvatskoj je općepoznato da je HDZ utemeljen na konzervativnom i nacionalnom idejno-političkom opredjeljenju, te da slijedom toga pokriva prostor desnog centra. Za razliku od njega, SDP je kao reformirana socijaldemokratska stranka proizašao iz dva izvora, a) iz bivšeg SKH-a, i b) iz izvorne socijaldemokratske stranke Hrvatske, nastale uoči prvih višestranačkih izbora. Radi se o stranci koja nastoji (i uspijeva) svojim programom zauzeti lijevi centar političkog prostora u $\mathrm{RH}$. 


\section{O VREMENU I RAZLOZIMA ZA FORMIRANJE VLADE DEMOKRATSKOG JEDINSTVA}

Vladu demokratskog jedinstva imenovao je Predsjednik $\mathrm{RH}^{19}$ i dobila je povjerenje Hrvatskog sabora početkom kolovoza 1991. godine.

To je vrijeme u kojem je Republika Hrvatska, provodeći disolucijski postupak od bivše SFRJ, nakon provedenih prvih višestranačkih demokratskih izbora donijela ključne odluke za svoju samostalnost i suverenost. Krajem 1990. donosi svoj Ustav, ${ }^{20}$ tijekom svibnja 1991. godine provodi referendum o svojoj samostalnosti. ${ }^{21} \mathrm{Na}$ osnovi odluke donesene na referendumu, Hrvatski je sabor u lipnju 1991. donio Ustavnu odluku o suverenosti i samostalnosti Republike Hrvatske, kojom je Republika Hrvatska proglasila svoju suverenost i samostalnost. ${ }^{22} \mathrm{Uz}$ ovu odluku, Sabor je donio na istoj sjednici Deklaraciju o proglašenju suverene i samostalne Republike Hrvatske $^{23}$ i Povelju o pravima Srba i drugih nacionalnosti u Republici Hrvatskoj. ${ }^{24}$ $\mathrm{Na}$ donesene odluke Hrvatski sabor je prihvaćanjem Brijunske deklaracije,$^{25}$ na poticaj međunarodne zajednice, prihvatio veto neprimjene od tri mjeseca, dajući još jednu šansu svim sudionicima da iznađu mirno rješenje prihvatljivo svima za razrješavanje krize SFRJ.

Međutim, vrlo brzo bilo je izvjesno da osigurano vrijeme mirnog rješavanja jugoslavenske krize donošenjem Brijunske deklaracije neće biti za tu svrhu iskorišteno.

Istodobno, kada je donesena Brijunska deklaracija, snage agresora (pobunjenih Srba i JNA) napale su i spalile selo Ćelije u istočnoj Slavoniji. Nije potrebno naglašavati da se radi o selu koje je pretežito (većinski) naseljeno Hrvatima. No,

19 U vrijeme formiranja Vlade demokratskog jedinstva na snazi je u izvornom tekstu Ustav Republike Hrvatske iz 1990. ("Narodne novine" broj 56/1990.) po kojem Republika Hrvatska ima polupredsjednički sustav u kojem predsjednik Republike imenuje predsjednika, potpredsjednika i članove Vlade, a Hrvatski sabor im (ne) daje povjerenje. Nakon imenovanja, predsjednik Vlade Republike Hrvatske dužan je najkasnije od 15. dana "predstaviti Vladu Zastupničkom domu i tražiti glasovanje o povjerenju Vladi" (čl. 12. st. 1. Ustava).

20 Ustav Republike Hrvatske donesen je 22. prosinca 1990., a objavljen u "Narodnim novinama" broj 56/1990.

${ }_{21}$ Hrvatski referendum o suverenosti i samostalnosti održan je 19. svibnja 1991. Na referendumu se odlučivalo o dva pitanja: "1. Jeste li za to da Republika Hrvatska, kao suverena i samostalna država, koja jamči kulturnu autonomiju i sva građanska prava Srbima i pripadnicima drugih nacionalnosti u Hrvatskoj, može stupiti u savez suverenih država s drugim republikama? (prema prijedlogu Republike Hrvatske i Republike Slovenije za rješenje državne krize SFRJ) i 2.) Jeste li za to da Republika Hrvatska ostane u Jugoslaviji kao jedinstvenoj saveznoj državi?" Na referendum je izašlo 83,56 \% stanovnika s pravom glasa, od čega je 94,17\% glasalo za prvo postavljeno pitanje, odnosno za suverenu i samostalnu Republiku Hrvatsku. Svega 4,18 \% glasača bilo je za njezin ostanak u Jugoslaviji kao saveznoj državi, a $1,2 \%$ listića bilo je nevažećih.

22 Ustavna odluka o suverenosti i samostalnosti Republike Hrvatske objavljena je u "Narodnim novinama" broj 31/1991.

23 Deklaracija o proglašenju suverene i samostalne Republike Hrvatske objavljena je u "Narodnim novinama" broj 31/1991.

24 Povelja o pravima Srba i drugih nacionalnosti u Republici Hrvatskoj objavljena je u "Narodnim novinama" broj 31/1991.

25 Brijunska deklaracija od 7. svibnja 1991. 
iako to nije tema ovog rada, ipak je potrebno ukazati da Brijunska deklaracija (kao ni bilo koji drugi akt) nije stavila izvan snage akte "o uspostavljanju neovisne, suverene i samostalne države Hrvatske donesene 25. lipnja 1991."26

Brijunska deklaracija, osim toga, niti u formalnom niti u materijalnom pravnom pogledu nije akt koji udovoljava ustavnopravnim kriterijima da bi to mogla učiniti. Prvo, radi se o deklaraciji, dakle političkom aktu koji po svom sadržaju, čak i kad sadrži neka prava i obveze, nije pravni akt. Njom se zapravo samo deklarira volja njezina donositelja na određeno postupanje ili djelovanje, ocjena nekog stanja i najava programskog pa tako i pravnog postupanja i buduće donošenje pravnih propisa kojima će te odnose regulirati. Osim toga, "O Brijunskoj deklaraciji nikada nisu odlučivali Sabor, a ni hrvatska Vlada. Nisu je nikada ni razmatrali. Nikada nije objavljena u službenom glasilu Narodnim novinama. Ako se Deklaracija uzme kao međunarodni ugovor dvojbeno je da li je potvrđena u skladu s Ustavom. Nije, prema tome, nikada ni unesena u unutarnji pravni poredak Republike Hrvatske.'27

Protekom moratorijskog vremena koje je osiguravao moratorijski period dolazi se do toga da će jedino biti moguće donijeti Odluku o raskidu državno-pravnih sveza na temelju kojih je Hrvatska zajedno s ostalim republikama i pokrajinama tvorila dotadašnju SFRJ. Takvu odluku Republika Hrvatska donijela je 8. listopada 1991. godine. $^{28}$

Međutim, pobunjeni hrvatski Srbi, vođeni velikosrpskom politikom iz Beograda i potpomognuti vanjskom agresijom od strane u to vrijeme tzv. dobrovoljačkih odreda iz Srbije i Crne Gore te s JNA, ne samo da zadržavaju do tada privremeno okupirane teritorije Republike Hrvatske, već odbijaju svaku raspravu o suverenosti i samostalnosti Republike Hrvatske u njezinim granicama koje je imala kao socijalistička republika bivše SFRJ, ne prihvaćaju bilo kakvu soluciju o Srbima u Hrvatskoj kao nacionalnoj manjini. Istovremeno provode progon hrvatskog i drugog nesrpskog, pa i srpskog stanovništva koje ne prihvaća velikosrpsku politiku i vlast pobunjenika na područjima pod njihovom kontrolom. I sve to uz povremene oružane atake na pojedinim područjima $\mathrm{RH}$, najavljujući otvoreni rat i odvajanje okupiranih teritorija od Republike Hrvatske i njihovo pripajanje novim državnim tvorevinama koje osnivaju poput države u kojoj žive svi Srbi. Agresori na Republiku Hrvatsku već tada su bili okupirali oko 25 posto njezina suverenog teritorija. S okupiranih područja, prema slobodnim gradovima slijevao se ogroman broj prognanih građana. Neki od njih su kao izbjeglice u druge zemlje nastojali sačuvati svoj i život članova svojih obitelji te im u stvarnom svijetu osigurati egzistenciju. No, najteže su svima padale pogibije, ranjavanja i u logore zatvaranja naših branitelja i civilnog stanovništva.

Toj ionako teškoj situaciji koja je s pravom nazvana dramatičnom, dodatno su doprinosila događanja na unutrašnjoj političkoj sceni. Naime, "dramatičnosti

26 Davorin R., “Stvaranje Hrvatske države 1991.”, Školska knjiga, Zagreb, 2017., str. 323.

27 Ibidem

28 Odluka Republike Hrvatske o raskidu državno-pravne sveze ..., donesena je 8. listopada 1991. i objavljena u "Narodnim novinama" broj 53/1991. 
situacije u hrvatskom društvu pridonosile su različite glasine o tome kako se vlast ne može nositi s trenutačnom nezadovoljavajućom situacijom. Stvarala se klima nezadovoljstva, defetizma i apatije. Prijetila je opasnost da će sukobi između stranaka, te brojne struje i skupine unutar nekih od njih, izazvati slom hrvatske politike. Govorilo se da radikali pokušavaju nasilno smijeniti i samog predsjednika Tuđmana zbog njegove umjerene politike, a zapravo je to bila razborita politika taktiziranja (i dobivanja na vremenu) sa snagama u Jugoslaviji i svijetu." ${ }^{29}$

Navedenim okolnostima treba svakako pridodati barem još dvije grupe pitanja i problema. Prvo, odmah nakon donošenja "božićnog” Ustava Republike Hrvatske većina srpskih zastupnika napustila je Hrvatski sabor, podnoseći uvjetovani zahtjev da će se u njega vratiti nakon što Sabor u dnevni red svoje sjednice uvrsti raspravu o položaju srpskog naroda (ne kao nacionalne manjine) u Republici Hrvatskoj (vidi Prilog br. 3). Takvim svojim činom po nekima onemogućili su za Srbe odnosno srpsku manjinu u "Hrvatskoj legitimnog institucionalnog predstavnika: politički se sukob pretvorio u nasilnu pobunu i rat". ${ }^{30}$

Stajalište uvaženog profesora Zakošeka, po mom sudu, samo je djelomično točno. Ponajprije i sam konstatira da je "oko dvije trećine" srpskih zastupnika napustilo Sabor. No, postavlja se pitanje zašto ona preostala trećina Srba u Saboru nisu i ne mogu biti legitimni institucionalni predstavnici Srba u Saboru? Je li razlog u tome što su oni članovi političkih stranaka s nesrpskim predznakom, ili zbog toga što ne pripadaju onoj skupini koja traži rješenje srpskog pitanja na programu velikosrpske politike koja polazi od teze da Srbi u Republici Hrvatskoj nisu i ne mogu biti nacionalna manjina, već su konstitutivni narod, koji ima sva prava i slobode u Hrvatskoj koje iz takvog statusa za njih proizlaze, uključivo pravo na samoodređenje s pravom na odcjepljenje od Republike Hrvatske.

$\mathrm{Na}$ ta pitanja uvaženi profesor ne daje odgovore, ali se oni iz stipulacije i sadržaja teksta njegova rada primjenom metode argumentom a contrario mogu izvesti. Ukoliko su ona točna, a protekom vremena kao takva su potvrđena, onda je sasvim jasno da nedostatak ovih tzv. legitimnih institucionalnih predstavnika Srba u Saboru nije uzrok zbog kojeg se "politički sukob pretvorio u nasilnu pobunu i rat", već je on sadržan u ostvarenju velikosrpske politike koja ima za cilj s pobunjenim Srbima u Hrvatskoj odvojiti dio njezina teritorija i pripojiti ga državi u kojoj žive svi Srbi.

Nesporna je činjenica da je radikalizacija sukoba uvjetovana velikosrpskom agresijom na Republiku Hrvatsku s jedne strane, te $\mathrm{s}$ druge strane nesporno iskazanom voljom ogromne većine hrvatskog stanovništva (s pravom glasa) kojom su se na provedenom referendumu opredijelili za samostalnu i suverenu Republiku Hrvatsku - utjecala na opozicijske stranke, osobito lijevog bloka predvođena SDPom, "da se priključi sveobuhvatnom hrvatskom nacionalnom konsenzusu oko uspostave i obrane samostalne hrvatske države". ${ }^{31}$

29 Gregurić, F., Vlada demokratskog jedinstva - Istina o Vukovaru i škola demokracije u Hrvatskoj, Školska knjiga, Zagreb, 2017., str. 45.

30 Zakošek, N.., "Struktura biračkog tijela i političke promjene u siječanjskim izborima 2000.", u Zborniku radova: Hrvatska politika 1990.-2000., o. c., str. 100.

31 Ibidem. 
Takvo opredjeljenje odgovaralo je SDP-u, naprosto stoga što je donošenjem Ustavne odluke o samostalnosti i suverenosti Republike Hrvatske, te Deklaracije o proglašenju suverene i samostalne Republike Hrvatske jedan od ključnih elemenata njegova predizbornog i izbornog programa prestao postojati. Radi se, kako je poznato, o tome da je u svom izbornom programu za izbore 1990. SDP imao točku "inzistiranja na očuvanju postojećeg uređenja jugoslavenske federacije". ${ }^{32}$ Iako je SDP bio svjestan da će svojim uključivanjem u sveukupni nacionalni konsenzus u uređivanju temeljnih konstitucionalnih pitanja Republike Hrvatske izgubiti ne samo simpatije, već i birače iz reda srpske nacionalne manjine, on se svjesno opredijelio za takav stav. Naprosto stoga što je bila u pitanju kako sloboda hrvatskog naroda i svih njezinih građana tako i pravo na postojanje samostalne suverene Republike Hrvatske.

Sve to je u cijeloj Hrvatskoj na građane i njezine institucije djelovalo frustrirajuće. Bilo je neupitno da je naša "nacionalna drama dosegla vrhunac i da se hitno trebaju donijeti odgovarajuće mjere, ovisno o situaciji i objektivnim mogućnostima". ${ }^{33}$

Jedno od sredstava koje bi moglo biti adekvatno za rješavanje hrvatske nacionalne drame te obrane njezina suvereniteta i samostalnosti bilo je formiranje Vlade demokratskog jedinstva, koja izražava nacionalno jedinstvo i spremnost da dosljedno sprovede volju građana Republike Hrvatske iskazanu u odluci donesenoj na svibanjskom referendumu.

\section{O POLITIČKOPRAVNIM POSTUPCIMA PA I KONTROVERZAMA U FORMIRANJU VLADE DEMOKRATSKOG JEDINSTVA}

Formiranje Vlade demokratskog jedinstva prošlo je određene faze dijelom iz političkih a dijelom iz formalnopravnih, obligatornih razloga. Politička faza njezina formiranja primarno se odnosi na dogovore između vladajuće stranke i opozicijskih stranaka zastupljenih u tadašnjem (prvom) sazivu Hrvatskog sabora. Po prirodi stvari, većina ovih razgovora protekla je između njih, a napose između vladajuće stranke i najjače opozicijske stranke, iza zatvorenih vrata. Daleko od očiju javnosti. Relativno brzo, tijekom prve polovice srpnja 1991., pozicija i opozicija postigle su suglasnost da postoje ozbiljni i neodložni razlozi od nacionalnog interesa zbog čega bi trebalo u formalnom i supstancijalnom, sadržajnom smislu formirati vladu koja će (neovisno o idejnopolitičkim razlozima između parlamentarnih stranaka) izražavati nacionalno jedinstvo i čvrstu opredijeljenost da brani i obrani hrvatsku slobodu, samostalnost, suverenitet i teritorijalni integritet. Međutim, tijekom razgovora otvorila su se pitanja koja zadiru u stranačke interese, iako u krajnjoj liniji nisu takvog značaja da bi mogla ta pitanja zaustaviti formiranje Vlade na osnovama

32 Vidjeti pobliže Čular, G., "Vrste stranačke kompeticije u razvoju stranačkog sustava", u Zborniku radova Hrvatska politika 1990.-2000., o. c., str. 132.

33 Gregurić, F., o. c., str. 45. 
velike koalicije. In concreto, javilo se pitanje kako nazvati tu vladu, a da se u njezinu imenu ne spominje riječ koalicijska, pogotovo ne velika koalicija. Neovisno o tome što ona u svom sadržaju to jest. Naime, ni vladajućoj stranci (HDZ-u), ni glavnoj opozicijskoj stranci (SDP-u) upotreba tih pojmova nije odgovarala. Vladajućoj stranci ponajprije stoga što bi time dala novog štofa svojim nezadovoljnicima i skupinama za dodatno prozivanje vodstva, pa, možda i pokušaja njegova rušenja.

Glavnoj opozicijskoj stranci (SDP), ali i nekim drugim opozicijskim strankama, iz razloga što bi javnim prihvaćanjem koalicije priznali da se definitivno odriču dijela svog predizbornog programa ili da daju potvrdu (i priznanje) kako je taj dio programa bio neprihvatljiv velikoj većini građana Hrvatske, koji su to jasno iskazali svojim očitovanjem na referendumu. Uz to, dio biračkog tijela iz reda srpskog etniciteta, koji je glasao za lijeve stranke, prije svega za SDP (koji ih je optuživao da su ih prevarili i izdali), dobio bi dodatnu osnovu za povredu svojih optužbi. Takve optužbe su za SDP iz tog biračkog tijela počele stizati odmah nakon donošenja Božićnog ustava Republike Hrvatske, 22. prosinca 1990., a znatno su se pojačale nakon donošenja Ustavne odluke o suverenosti i samostalnosti Republike Hrvatske.

Gornji razlozi motivirali su vodstva pozicijske stranke i stranaka opozicije da na dogovorenom programu, od zajedničkog nacionalnog interesa i strateških nacionalnih ciljeva, imenuju Vladom demokratskog jedinstva, a ne npr. Vladom velike koalicije ili Vladom nacionalnog jedinstva, što je ona u svim svojim bitnim sadržajnim elementima bila.

Uzgredno, kad raspravljam o formiranju Vlade demokratskog jedinstva, moram ukazati na jednu nelogičnost, moglo bi se reći špekulaciju kojom se nastoji umanjiti uloga SDP-a pa i samog Ivice Račana u tom poslu. Ona počiva na tezi da su Ivica Račan i SDP pristupili ${ }^{34}$ koaliciji ili da su samo podržali ${ }^{35}$ i dali suglasnost za Vladu demokratskog jedinstva. Drugim riječima, hoće se reći da su SDP i Ivica Račan prihvatili i pristupili ovoj velikoj koaliciji kad je ona bila dogovorena i gotovo u cijelosti perfektuirana. Ako je navedena teza netočna, onda ne samo da je to izvrtanje novije povijesti, već je nekorektno kako prema SDP-u, tako i prema njegovu pokojnom predsjedniku Ivici Račanu. Razmotrimo stoga malo ovaj problem, ali na osnovi činjenica i logičnih postavki s jedne strane, a s druge strane temeljem dostupnih dokumenata.

Prvo, valja ukazati na činjenicu da ovakva velika koalicija u prvom sazivu Hrvatskog sabora nije bila moguća, ali ni potrebna ukoliko nema dogovora između dviju najsnažnijih parlamentarnih stranaka, a to su HDZ i SDP. Naprosto stoga što je HDZ sam u tom sazivu Sabora imao natpolovičnu većinu 58,40 posto od ukupnog broja zastupnika, a SDP je bio najjača opozicijska stranka sa 30,48 posto mandata. Sve ostale parlamentarne stranke, Koalicija narodnog sporazuma (dalje: KNS) i SDS zajedno s nezavisnima imali su samo 11,11 posto. Koalicija HDZ-a s njima, bez SDP-a, ništa kvalitativno ne nosi. Naime, takva bi koalicija imala samo

34 Vidjeti izjave da je Vladi demokratskog jedinstva pristupio SDP i Ivica Račan npr. kod Manjkas, M., Sasvim nepoznati Tuđman, dokumentarni film na https://m.youtube.com/watch.

35 Tako Gregurić, F., u svojoj knjizi, o. c., str. 47. 
nešto više ruku u natpolovičnoj većini, ali ukupno ne bi ostvarila ni kvalificiranu dvotrećinsku (2/3) većinu od ukupnog broja zastupnika u Hrvatskom saboru (da bi npr. mogla donositi odluke za koje ustav traži takvu kvalificiranu većinu kod njihova izglasavanja). Osim toga, koalicija bez SDP-a nema u idejnopolitičkom smislu esencijalnu vrijednosnu komponentu koja pokazuje da su se većinske stranke pozicije i opozicije, unatoč svojim ideološkopolitičkim razlikama, dogovorile radi potrebe ostvarivanja i zaštite političkih interesa i ciljeva od nacionalnog interesa, te zbog toga privremeno svoje ideološkopolitičke razlike stavile svjesno po strani. Prema tome, sasvim je jasno da su ovi odlučujući razlozi bili osnova za HDZ i SDP, te ostale oporbene stranke o čemu su morali postići prethodni dogovor, a onda se i sami opredijeliti da će ući u veliku koaliciju i istodobno je otvoriti svim parlamentarnim strankama kako bi u njoj, ako žele, mogli i sudjelovati. Dogovor između HDZ-a i SDP-a o velikoj koaliciji bilo je moguće postići zbog okolnosti razloga i događaja koji su koaliciju i prouzročili, o čemu je već bilo riječi u ovom radu. Dakako, u dogovaranju o velikoj koaliciji, što se odvijalo između HDZ-a i SDP-a, sudjelovali su samo stranački predsjednici, a o tijeku dogovora bilo je, bar kad je u pitanju SDP, upoznato samo najuže rukovodstvo stranke.

Tek kad je taj dogovor postignut, otvorio se prostor za međustranački dogovor svih parlamentarnih stranaka, odnosno njihovih rukovodstava, o velikoj koaliciji i bitnim političkim programskim osnovama na kojima će ona počivati, odnosno na kojima će se izraditi program za koalicijsku Vladu i Sporazum saborskih zastupnika što ga stranke trebaju potpisati i na osnovi kojeg će se formirati koalicijska vlada, nazvana (kako je znano) Vladom demokratskog jedinstva.

Navedenu elaboraciju o prethodnoj fazi u nastanku Vlade demokratskog jedinstva na indirektan način potvrdio je i sam predsjednik Franjo Tuđman, što u svojoj knjizi na specifičan način svjedoči Franjo Gregurić, predsjednik Vlade demokratskog jedinstva. On kaže da: "Predsjednik Tuđman, svjestan kritičnog trenutka za povijesni dovršetak svojeg sna, predložio je stvaranje velike koalicije, a pregovore o sastavu i suradnicima (Slaven Letica, Slavko Degoricija, Milan Ramljak, Dražen Budiša, Mladen Vedriš) koji bi s predsjednicima parlamentarnih stranaka sastavili prijedlog sporazuma i kandidate za pojedina ministarska mjesta, prepustio bi nama." ${ }^{36}$ Zašto sam slobodan izložiti tvrdnju da je i sam predsjednik Tuđman na indirektan način potvrdio postojanje prethodne faze dogovaranja za stvaranje velike koalicije između zapravo njega kao predsjednika HDZ-a i Ivice Račana kao predsjednika SDP-a? Dijelom zbog toga što sam o njima i sam nešto znao, jer nas je upoznao Ivica Račan. Zatim, posve je jasno da u situaciji u kojoj se tada nalazila Republika Hrvatska, pa i sam Franjo Tuđman kao predsjednik stranke unutar HDZ-a, on (predsjednik Tuđman) nije mogao niti smio ni sebe ni Hrvatsku dovesti u takvu političku situaciju da predloži veliku koaliciju, a da se ona ne prihvati. To bi imalo ozbiljne političke reperkusije kako na unutarnjem političkom planu, tako i na međunarodnom planu. Na unutarnjem političkom planu bilo bi ozbiljnih reperkusija prvo unutar HDZ-a, a drugo između parlamentarnih stranaka, a o moralnom jedinstvu i spremnosti

36 Ibidem. 
stanovništva i branitelja da brane suverenitet i samostalnost Hrvatske od agresije da se i ne govori. A tako su bile ozbiljne moguće reperkusije i na međunarodnom planu, pogotovo ako se ima u vidu da je to vrijeme u kojem je na snazi Brijunska deklaracija. Prema tome, predsjednik Tuđman morao je imati (a što se tiče SDP-a i Račana je i imao) čvrsto uvjerenje da će prijedlog o velikoj koaliciji biti prihvaćen i da će doći do formiranja Vlade demokratskog jedinstva.

Tek nakon što je u prethodnoj fazi testirana ideja o velikoj koaliciji i višestranačkoj vladi, predsjednik Tuđman se opredijelio da tu ideju stavi na stol svim stranačkim prvacima čije su stranke zastupljene u Hrvatskom saboru. No, to je vremenski bilo puno prije no što u svojoj knjizi navodi dr. Gregurić, o čemu svjedoči i tadašnji savjetnik predsjednika Tuđmana prof. dr. Slaven Letica.

Prema profesoru Letici, došlo je do "sastanka državnog vodstva i svih stranačkih prvaka u Banskim dvorima 26. lipnja 1991., navečer oko osam sati" u uredu predsjednika Tuđmana. Na tom sastanku, pored ostalog, razgovaralo se "o zaključcima netom završenog sastanka s čelnicima parlamentarnih stranaka i njihovoj spremnosti za konstitutivni dogovor o tako važnom pitanju kao što je pitanje rata i mira u Sloveniji i Hrvatskoj. Tijekom razgovora javila se ideja o potrebi i mogućnosti stvaranja višestranačke vlade ...". I dalje Letica navodi: "Nakon inicijativnih razgovora (na kojima je otpočetka s ostalim opozicijskim prvacima sudjelovao i Račan, primjedba M.A.) i postignutog načelnog suglasja oporbenih prvaka o mogućnosti formiranja višestranačke vlade, (...) - u dogovoru s Josipom Manolićem odlučio je (predsjednik Tuđman, primjedba M. A.) da mandatar za sastav višestranačke vlade, koja je nazvana Vladom demokratskog jedinstva, bude dr. Franjo Gregurić." ${ }^{\prime 37}$ Neki autori ${ }^{38}$ navode da je predsjednik Tuđman morao razgovarati s opozicijom zbog prijetnji državnog udara, ali i otkazivanja poslušnosti jakih ljudi stranačke desnice. Ti autori potvrđuju da su ti razgovori vođeni prije formiranja Vlade demokratskog jedinstva.

Drugo, ne bi se smjelo zaboraviti da je Ivica Račan kao predsjednik SDP-a, dakle i u svoje i u ime stranke, uputio dr. Franji Tuđmanu kao Predsjedniku Republike Hrvatske otvoreno pismo u kojem je sadržan "Prijedlog o imenovanju Koalicijske vlade demokratskog jedinstva i Predsjedničkog vijeća". ${ }^{39}$

Prijedlog je upućen predsjedniku Tuđmanu s molbom da ga se prihvati, "s obzirom na dramatičnu situaciju u kojoj se nalazi naša domovina, i vodeći računa o potrebi objedinjavanja svih demokratskih snaga ...". Samo otvoreno pismo koje u privitku sadrži gornji prijedlog upućeno je predsjedniku Republike Hrvatske Franji Tuđmanu 2. kolovoza 1991. Neposredni povod da se Račan obrati predsjedniku Tuđmanu

37 Letica, S., "Vlada demokratskog jedinstva bila je conditio sine qua non obrane Hrvatske", Prilog na stranicama 54-60. u knjizi: Vlada demokratskog jedinstva ..., Gregurić, F., o. c., str. 57. i 58.

38 Tako Čuljak, T., Operacija ŠTIT - treći dio na https://novenews.net/hr/znanost/operacija-stit-trecidio-48, posjet stranici 2. listopada 2019. O postojanju opasnosti državnog udara piše i J. Manolić: Vidi njegovu knjigu: Politika i domovina, Moja borba za suverenu i socijalnu Hrvatsku, Golden Marketing Tehnička knjiga, Zagreb, 2015.

39 Račan, I., Otvoreno pismo predsjedniku Republike Hrvatske dr. Franji Tuđmanu od 2. kolovoza 1991., broj: 02/P-135/1-91. 
otvorenim pismom bio je, između ostalog, zaustavljanje trzavica i strančarenje između predstavnika parlamentarnih stranaka koje su (nakon postignutog političkog dogovora o velikoj koaliciji i višestranačkoj vladi) radile na formiranju prijedloga kandidata za članove Vlade demokratskog jedinstva i pripremale međustranački Sporazum. ${ }^{40}$ No, u sadržajnom smislu Prijedlog je veoma interesantan, sadržajno nabijen i obuhvatan. U njemu se prvi put u jednom pisanom dokumentu govori o Vladi demokratskog jedinstva, a ako se komparira njegov sadržaj sa sadržajem Sporazuma parlamentarnih stranaka o Vladi demokratskog jedinstva, onda je sasvim vidljivo da je on bio političko-pravna podloga za Sporazum, i u tom smislu, u odnosu na njega, on je, pored toga što je politički, istovremeno i preparatorni pravni akt. ${ }^{41}$ Uostalom, sam prijedlog sadrži i mogući nacrt Sporazuma s elementima na kojima bi trebao počivati (vidjeti Prilog br. II.). Sam prijedlog (inicijalni tekst) Sporazuma napisao je prof. dr. sc. Milan Ramljak. ${ }^{42}$

Bez potrebe daljnjeg upuštanja u elaboriranje okolnosti i događanja koja su egzistirala u vremenu formiranja Vlade demokratskog jedinstva, pa i u odnosu na ulogu SDP-a i samog Ivice Račana, smatram da su izložena argumentacija i sami dokumenti jasno pokazali zbog čega je i u kojim okolnostima osnovana Vlada demokratskog jedinstva s jedne strane. S druge strane da SDP i Ivica Račan nisu u njezinu formiranju bili maltene statisti koji su joj "pristupili" tek kad je osnovana ili eto samo da bi "podržali" sporazum - i sastav Vlade, kako se sve češće može čuti od onih koji žele iz sebi znanih interesa i pobuda malko redizajnirati našu noviju povijest. Pa i na ovom pitanju.

Interesantna je činjenica da postoje kontroverze i oko samog datuma osnivanja Vlade demokratskog jedinstva. Tako na portalu Vlade Republike Hrvatske ${ }^{43}$ iščitavamo da je ona osnovana i djeluje od 17. srpnja 1991., dok u svojoj knjizi Vlada demokratskog jedinstva - Istina o Vukovaru i škola demokracije u Hrvatskoj, Franjo Gregurić navodi kako su on kao predsjednik, zatim potpredsjednici i ministri u Vladi demokratskog jedinstva na dužnosti od 2. kolovoza 1991. U istoj knjizi on nadalje navodi da je Hrvatskom saboru predstavio Vladu demokratskog jedinstva i njezin program 3. kolovoza 1991. i zatražio glasanje o povjerenju u skladu s Ustavom Republike Hrvatske. Navedene kontroverze lako je otkloniti ako se obrazloži postupak formiranja Vlade demokratskog jedinstva, dakako, polazeći od odredbi Ustava Republike Hrvatske koje su na snazi od 1991.

40 "Koalicijskim sporazumima utvrđuje se ponajprije sadržaj politike, podjela resora i rješavaju proceduralna pitanja, uključujući i pitanja koalicijske discipline u glasovanju u parlamentu te mehanizama za razrješavanje sukoba među koalicijskim partnerima i dr.". Vidjeti noticu "Koalicijska vlada" u Izborni leksikon, str. 190., Politička kultura, Zagreb, 2003., autora Kasapović, M.

41 Pod preparatornim pravnim aktom razumijevam političko-pravni akt kojim su se stranke dogovorile o osnovnim pitanjima za uređivanje određenog društvenog odnosa i preuzele obvezu da će to ugraditi odnosno pravno urediti odgovarajućim pravnim aktom.

42 Vidjeti pobliže Letica, S., Prilog, o. c., str. 57.

43 Neke od nesuglasica pa i glede datuma formiranja Vlade demokratskog jedinstva između službenih podataka i navoda pojedinih autora najvjerojatnije su rezultat nedovoljne informiranosti i/ili neznanja. Naime, teško mi je povjerovati da se oni iznose radi redizajniranja naše novije povijesti. 
Tada važeće odredbe Ustava Republike Hrvatske koje se odnose na Predsjednika Republike uređivale su ga kao polupredsjednički sustav. U takvom modelu Predsjednik (uz ostale) ima posebne ovlasti glede Vlade Republike Hrvatske. Pored ostaloga, Predsjednik Republike Hrvatske "imenuje i razrješuje dužnosti predsjednika Vlade Republike Hrvatske" ${ }^{44}$ a na njegov se prijedlog "imenuje i razrješuje dužnosti njezine potpredsjednike i članove" ${ }^{45}$ Iz navedenih odredbi razvidno je da je imenovanje predsjednika Vlade odvojeno od imenovanja i razrješenja njezinih potpredsjednika i članova, snagom samog Ustava. Nadalje, "Vlada je odgovorna predsjedniku Republike i Zastupničkom domu Sabora Republike Hrvatske". ${ }^{46}$

Parlamentarni postupak u formiranju Vlade Republike Hrvatske u vrijeme egzistiranja polupredsjedničkog sustava odvojen je od imenovanja predsjednika Vlade njezinih potpredsjednika i članova i čini posebnu podfazu u formiranju Vlade. Parlamentarna faza sadržava postupak predstavljanja Vlade Zastupničkom domu te glasovanje o povjerenju Vladi koje traži od Sabora predsjednik Vlade nakon što je i predstavi. ${ }^{47}$

Navedene odredbe Ustava jasno razlikuju i međusobno odvajaju pojedine podfaze u formiranju Vlade Republike Hrvatske, koje su važile i primjenjivale se kod formiranja Vlade demokratskog jedinstva.

Prvo je predsjednik Republike Hrvatske morao imenovati predsjednika, a onda je na njegov prijedlog imenovao njezine potpredsjednike i članove. Imenovanje potpredsjednika i članova Vlade ne mora biti istovremeno, a u pravilu i nije. To je sasvim vidljivo iz usporedbe datuma imenovanja (preuzimanje dužnosti) i za pojedine potpredsjednike i članove Vlade demokratskog jedinstva. Međutim, važno je ukazati na činjenicu da je datum imenovanja predsjednika Vlade demokratskog jedinstva odlučujući za računanje od kada postoji dogovor o velikoj koaliciji. Taj datum također potvrđuje prethodnu fazu u dogovaranju velike koalicije, za koju sam ustvrdio da nije bila moguća ako u njoj ne sudjeluju najjača stranka pozicije (njezin predsjednik) i najjača stranka opozicije (njezin predsjednik). Iz raspoloživih podataka o imenovanju predsjednika Vlade demokratskog jedinstva, njezinih potpredsjednika i članova (koji se podudaraju i koji su službeno objavljeni), vidljivo je da je predsjednik Vlade demokratskog jedinstva na tu dužnost imenovan 17. srpnja 1991. Potpredsjednike i članove Vlade demokratskog jedinstva imenovao je na dužnost predsjednik Republike, a na prijedlog predsjednika Vlade, sukcesivno počevši od 31. srpnja pa nadalje.

Sabor Republike Hrvatske, tadašnji njegov Zastupnički dom, izglasao je povjerenje predsjedniku, potpredsjednicima i članovima Vlade demokratskog jedinstva kako ih je predložio njezin predsjednik i zatražio glasovanje o povjerenju nakon što ih je predstavio u parlamentarnom domu.

\footnotetext{
44 Vidjeti alineju 3. stavka 1. članka 98. Ustava Republike Hrvatske, "Narodne novine” broj 56/1990.

45 Alineja 4. stavka 1. članka 98. Ustava Republike Hrvatske, o. c.

46 Članak 111. stavak 1. Ustava Republike Hrvatske, o. c.

47 Članak 112. Ustava Republike Hrvatske.
} 
Prilika je ukazati da izglasavanje povjerenja nije konstitutivni akt od kojeg bi se moglo računati nastajanje velike koalicije. Zapravo taj čin nije konstituirajući u polupredsjedničkom sustavu ni za određivanje roka od kada teče dužnost imenovanom predsjedniku, potpredsjedniku i članovima Vlade demokratskog jedinstva Republike Hrvatske.

No, ustavna je činjenica nešto drugačija s obzirom na svoje učinke ako Sabor ne bi dao (izglasao) povjerenje toj Vladi kao cjelini. Ona tada pada i mora se pokrenuti postupak novog imenovanja i traženje izglasavanja povjerenja za novu vladu.

O svim detaljima tog postupka, uključivo i situaciju kad kod izglasavanja povjerenja, povjerenje ne dobije predsjednik Vlade ili samo neki od članova vlade zaslužuje posebnu elaboraciju, ovdje se ne bavim. Ovdje nam je pitanje eventualnog neizglasavanja povjerenja važno da upozorimo da i tada, neovisno o dubini političkog problema, nužno ne pada i/ili ne mora doći do raspada velike koalicije. Naime, za sudionike velike koalicije taj događaj može biti razlogom njezina raspada, ali i potreba da se pokrene novi ciklus formiranja koalicijske vlade na istovjetnom i/ ili revidiranom koalicijskom programu i sporazumu između koalicijskih partnera.

Što se tiče Vlade demokratskog jedinstva Republike Hrvatske, ona je dobila povjerenje Sabora na zajedničkoj sjednici sva tri vijeća 3. kolovoza 1991. i djelovala je do 12. kolovoza 1992., kada je nakon provedenih izbora za II. saziv Hrvatskog sabora imenovana IV. Vlada Republike Hrvatske.

\section{OSVRT NA USPJEHE VLADE DEMOKRATSKOG JEDINSTVA}

Vlada demokratskog jedinstva djelovala je u teškom i nepovoljnom vremenu koje je u bitnom obilježavala agresija na Republiku Hrvatsku.

Unatoč tim i takvim okolnostima i zbivanjima, smatram da je njeno postojanje iznimno značajno za Republiku Hrvatsku i sve njezine građane, kako zbog njezina doprinosa obrani slobode, samostalnosti i suverenosti Republike Hrvatske te njezina međunarodnog priznanja, tako i zbog otvaranja i provođenja tranzicijskog i transformacijskog procesa u njezinoj gospodarskoj i svim drugim djelatnostima.

Ovaj rad, s obzirom na prostorno ograničenje koje proizlazi iz njegove namjene, ne može se detaljnije baviti rezultatima rada Vlade demokratskog jedinstva. No, unatoč tome i s druge strane činjenici da je djelovala samo nešto više od jedne godine, treba spomenuti, pa makar taksativno, njezine rezultate. Jer oni su od osobitog značaja za Republiku Hrvatsku i sve njene građane. Po meni, najveći i najznačajniji rezultat Vlade demokratskog jedinstva vezan je uz činjenicu homogeniziranja nacionalnog bića i jačanja jedinstva svih državljana Republike Hrvatske u odlučnosti i spremnosti da brane i obrane svoju slobodu te samostalnost, suverenost i teritorijalnu cjelovitost Republike Hrvatske. To su oni potvrdili svojim ogromnim odzivom na zahtjev Vlade demokratskog jedinstva da se u tu svrhu stave na raspolaganje Republici Hrvatskoj. Vlada demokratskog jedinstva uspješno je osigurala nabavku oružja i druge vojne opreme za naše branitelje, zatim je uspjela organizirati proizvodnju 
oružja i opreme za HV, s velikim uspjehom osigurala je prihvat, zbrinjavanje i skrb za prognane i izbjegle, uključivo odgoj i obrazovanje njihove djece. Iako nije bilo od strane hrvatskih vlasti proglašenja rata ${ }^{48}$ uspješno je u ratnim uvjetima organizirano funkcioniranje gospodarstva i svih javnih službi javnih i drugih usluga. Tijekom njezina djelovanja, a ni kasnije, unatoč ratnim uvjetima i velikom broju prognanih i izbjeglih građana, u Hrvatskoj nije bilo oskudica ni gladi. Dijelom i zbog uspješnog povezivanja Hrvatske s iseljenom Hrvatskom, njihove svekolike pomoći i pomoći međunarodne zajednice. Vlada demokratskog jedinstva uspješno je, zajedno s drugim činiocima vlasti Republike Hrvatske, napose s Predsjednikom Republike Hrvatske, radila na međunarodnim odnosima i boljem uključivanju i pozicioniranju Republike Hrvatske u međunarodnu zajednicu. Nemali su njezin doprinos i zasluge za međunarodno priznanje (15. siječnja 1992.) Republike Hrvatske, te njezin prijem (22. svibnja 1992.) u punopravno članstvo UN-a. Na unutrašnjem planu doprinijela je uspostavljanju temelja ustavnopravnog poretka i njegove provedbe, zatim monetarnog, bankarskog i carinskog sustava, prilagodila fiskalnu politiku ratnim uvjetima i državama građanskog tržišnog gospodarstva i vladavine prava i drugim vrednotama vrijednosnog sustava demokratskog društva. Započela je rad na reformi lokane i regionalne samouprave, poreznog sustava, pretvorbi društvenog kapitala, te na transformaciji samoupravnog društvenog vlasničkog gospodarskog sustava u građanski sustav gospodarskih odnosa, u sustav zasnovan na jamstvu privatnog prava vlasništva, slobodnog tržišta i slobodnog poduzetništva itd. ${ }^{49}$

Zapravo bi se moglo reći da je Vlada demokratskog jedinstva otvorila i otpočela u ratnim uvjetima sve ključne reforme koje moraju osigurati tranziciju i transformaciju hrvatskog društva iz samoupravno-socijalističkog u građansko-demokratsko i tržišno-kapitalističko društvo. U tom je poslu imala uspjeha, ali i promašaja. Najveći prigovori koji joj se stavljaju na teret odnose se na propuste i promašaje u provedbi pretvorbe i privatizacije, kako u odabiru modela, tako i u njegovu ozakonjenju, ali i provođenju u praksi. No, o tom, možda u nekom drugom radu.

\section{ZAKLJUČAK}

Vlada je demokratskog jedinstva formirana i djelovala je u iznimno teškim i opasnim vremenima po građane i njihovu domovinu Republiku Hrvatsku. Nastala je u ratnim uvjetima kada je već četvrtina hrvatskog teritorija bila privremeno okupirana od agresora. Danas s pravom možemo reći da je ona nastala iz razloga borbe za ostvarivanje političkih interesa i ciljeva od nacionalnog, pa i konstitucionalističkog

48 To što hrvatske vlasti nisu službeno proglasile rat ne znači da agresiju na Hrvatsku i rata protiv nje u stvarnosti nema s jedne strane, a s druge strane da nitko drugi nije proglasio ratno stanje. Naime, Mile Martić, zapovjednik pobunjenih Srba,, već je 17. kolovoza 1990. godine putem Radio Knina proglasio ratno stanje, nakon čega je otpočela otvorena pobuna protiv Republike Hrvatske.

49 O nekim uspjesima Vlade demokratskog jedinstva možemo se informirati na Središnjem državnom portalu. Vidi npr. noticu 3. Vlada RH 17. srpnja 1991. - 12. kolovoza 1992. na https://vlada.gov.hr>ovladi>3-vl... 
državnog značaja za Republiku Hrvatsku i sve njezine državljane. Riječju, nastala je iz nužde.

Pitanje njezina formiranja na načelima i programu velikih koalicija dodatno je motivirano, poglavito kod vladajuće stranke HDZ, unutrašnjim sukobima struja i skupina, na pitanjima kakvu obrambenu i nacionalnu politiku voditi u Republici Hrvatskoj. Neki autori navode kao jedan od odlučujućih razloga (uz ratne razloge) sukobe u HDZ-u, pa i mogućnosti svrgavanja s vlasti predsjednika Tuđmana planiranim državnim udarom. ${ }^{50}$ Ovo navodim samo kao mogući razlog, ne radi toga da bih ga istraživao i ovdje potvrdio i/ili demantirao, već naprosto da bih jasnije ukazao na okolnosti, događanja i vrijeme u kojem je formirana i djelovala Vlada demokratskog jedinstva. Osim toga, svi ti razlozi pokazuju da je kako za vladajuće tako i za opozicijske stranke bilo malo prostora da se ne uključe u veliku koaliciju i na njezinu programu formiraju Vladu demokratskog jedinstva. U takvim okolnostima manje je važno tko je i kada inicirao i predložio veliku koaliciju, daleko je važnije da je ona nastala i da je njezin program u osnovi ostvarila Vlada demokratskog jedinstva. Međutim, radi povijesne istine, važno je ova pitanja objektivnim znanstvenim metodama istražiti i doći do znanstvene istine koja ima razumno utemeljenje i objašnjenje. Prije svega, radi toga da točnu i vjerodostojnu informaciju o Vladi demokratskog jedinstva imaju nove generacije, a osobito radi toga da ona i ubuduće bude faktor, pa dijelom i ogledni model kako se organizirati i djelovati u hrvatskom društvu kad su općenacionalni interesi i ciljevi državljana Republike Hrvatske, pa i ona sama - ugroženi i u opasnosti, neovisno o razlozima koji su do takve ugroze i opasnosti doveli.

\section{PRILOZI I - III}

Prvi je prilog Odluka o prekidu sudjelovanja u radu Sabora koju su Saboru poslali srpski (njih 11) zastupnici. Ona je značajna barem iz dva razloga.

Njome se od Sabora Republike Hrvatske zahtijevaju određene sasvim konkretne odluke i postupanja koja se postavljaju kao minimalni uvjeti da bi Sabor mogao funkcionirati kao demokratski parlament. Sama zahtijevanja u sebi sadrže naredbodavne elemente čime se Hrvatski sabor postavlja u podređenu poslušno-izvršnu ulogu njih kao predstavnika srpskog naroda. Drugim riječima, iz supstancijalnog sadržaja njihova zahtjeva može se očitati njihovo ponašanje kao subordiniranog subjekta prema Saboru, ali i stav da Srbi u Hrvatskoj moraju imati u odnosu na Hrvate položaj dominacije, koji je u blažoj verziji poznat kao položaj starijeg brata. Drugo, ovom Odlukom traži se i uvjetuje njihovo sudjelovanje u radu Sabora "otvaranjem rasprave o ustavno-pravnom položaju Srba u Hrvatskoj kao konstitutivnog i političkog naroda", čime se jasno odbija položaj Srba u Hrvatskoj kao nacionalne manjine. Tako postavljena zahtijevanja u svom sadržajnom smislu zapravo su jasno iskazala osnove na kojoj velikosrpska

${ }_{50}$ Čuljak, T., Operacija ŠTIT - treći dio, o. c. 
politika ima namjeru provoditi svoju agresiju prema Hrvatskoj sa secesionističkim ciljevima. Za dobre poznavatelje prilika i odnosa između nositelja velikosrpske politike i službene hrvatske politike bilo je jasno da se ovom odlukom prekidaju dijalozi u traganju za mirnim rješenjem tzv. jugoslavenske krize, a u Hrvatskoj konkretnih hrvatsko-srpskih odnosa. Navedena Odluka je uvod, najava i još jedan od mogućih opravdavajućih akata za nastupajući agresorski rat protiv Hrvatske, koji velikosrpska politika planira povesti.

Drugi je prilog Otvoreno pismo predsjednika SDP-a Ivice Račana predsjedniku Republike Hrvatske s prilozima. Pismo je poslano 2. kolovoza 1991., da bi dodatno ojačalo poziciju predsjednika Tuđmana (kako u odnosu prema drugim opozicijskim strankama, tako, osobito, i unutar HDZ-a) u provedbi dogovorne velike koalicije, te da se okonča formiranje Vlade demokratske vlasti.

Treći je prilog tekst Sporazuma koji su prihvatile i potpisale sve (osim HSS-a) parlamentarne stranke, obvezujući se na provedbu projekata velike koalicije putem Vlade demokratskog jedinstva. Pored ostalog, on je značajan jer se iz njegova sadržaja može iščitati ne samo tko su subjekti velike koalicije, već i koji su uzroci njezina nastanka, zatim koji su politički interesi i ciljevi velike koalicije, te kako će biti sastavljena Vlada demokratskog jedinstva i koje su njezine zadaće.

\section{Prilog I.}

Prijepis teksta Odluke o prekidu sudjelovanja u radu Sabora koju su poslali srpski zastupnici citiramo u cijelosti, među ostalim, i zbog njegova sada već povijesnog značenja. On glasi:

"Mi, pripadnicisrpskog naroda, zastupniciu Saboru RepublikeHrvatske, donosimo odluku o prekidu svog učešća u radu Sabora. Ova odluka je uslovljena slijedećim činjenicama: Stanje na rubu krvoprolića uzrokovano je nacionalšovinističkim postupcima stranke na vlasti odnosno njenog rukovodstva. Ovakvi postupci imaju svoj kontinuitet od predizborne kampanje, preko inauguracije nove vlasti, izmjena postojećeg i usvajanje novog Ustava, do brutalnog napada na JNA i Ustavni poredak SFRJ. U službu svega ovoga stavljeno je sistematsko širenje straha preko potpuno stranačkih kontrolisanih sredstava javnog informiranja, a kao pokriće i s krajnjim ciljem stvaranja stranačke vojske po uzoru na fašističke formacije.

Ustavnim rješenjima i praktičnom politikom srpski narod u Hrvatskoj doveden je u položaj građana drugog reda u vlastitoj domovini.

Žalosna je činjenica da stranka na vlasti ne izražava spremnost da poštuje čak i Ustav koji je sama donijela, a u smislu poštivanja demokratskih normi koje su u njemu zapisane, uključujući i nepoštivanja osnovnih ljudskih prava i sloboda. Srbi postaju narod koji je nepoželjan u politici, u vlasti, u policiji, u sudstvu, na rukovodećem položaju.

Čitavim nizom postupaka odriče se antifašističko određenje Hrvatskog naroda u jednom historiskom periodu, što je elementarni preduslov ulaska u demokratsku 
Europu. Kakvo je stvarno lice demokracije kojoj smeta ime Trga žrtava fašizma? Svog antifašističkog opredjeljenja srpski narod u Hrvatskoj se ne može odreći.

Na samom rubu ponora iz koga su naši narodi izašli prije nešto više od 45 godina plativši to neizmjerno, a u ime vlastite savjesti i duga prema narodu kojem pripadamo od Sabora Republike Hrvatske zahtijevamo:

1. Hitno i bezuslovno razoružavanje svih formacija stvorenih suprotno pozitivnim ustavnim i zakonskim odredbama,

2. Vraćanje broja pripadnika aktivnog i rezervnog sastava policije na stanje prije 30. maja 1990. godine,

3. Provođenje postupka utvrđivanja političke odgovornosti državnih organa Republike Hrvatske, te jamstvo za provođenje krivičnog postupka protiv pojedinaca koji su svojim odlukama i aktivnošću uzeli direktno učešće u ilegalnom naoružavanju, a u cilju obračuna sa JNA i srpskim narodom.

4. Hitno zaustavljanje bezočne antisrpske kampanje kao i brutalnog progona svih političkih neistomišljenika.

Ovo smatramo minimalnim uslovima da Sabor uopšte može funkcionisati kao demokratski parlament.

Konačno, naše učešće u radu Sabora, a u interesu hrvatskog naroda i srpskog naroda u Hrvatskoj uslovljavamo otvaranjem rasprave o ustavno-pravnom položaju Srba u Hrvatskoj kao konstitutivnog i političkog naroda.

Izražavamo duboku vjeru i iskrenu nadu da će srpski narod u ovom teškom vremenu smoći snage da zbijenih redova sačuva puni nacionalni identitet i dostojanstvo, te da zajedno sa hrvatskim i drugim narodima i narodnostima dade svoj doprinos za mirno rješavanje svih problema i sporova."

(Teleks 163D,... primljen 31. siječnja 1991., privatna arhiva)

Ispod teksta koji je teleksom 163D zaprimljen kao akt i poslan predsjedniku Sabora Republike Hrvatske 31. siječnja 1991. godine, slijedi popis imena i prezimena jedanaest zastupnika Sabora Republike Hrvatske.

U navedenoj Odluci izrijekom se traži i uvjetuje sudjelovanje u radu Sabora Republike Hrvatske 'otvaranjem rasprave o ustavno-pravnom položaju Srba u Hrvatskoj kao konstitutivnog i političkog naroda', čime se, zapravo, jasno odbija položaj Srba u Hrvatskoj kao nacionalne manjine i šalje poruka o neprihvaćanju tog statusa.

Izvor: privatna arhiva autora 


\section{Prilog II.}

Prilog II

STRANKA DEMOKRATSKIH PROMJENA.

H $\mathrm{B}$ V A $A$ T S K E

Brcj: 02/P-135/1-91.

Zagret, 2.kalovoza. 1991.

PREDSJEDNIK REPUBLIKE

HRVATSKE

Dr. Franjo Tudman

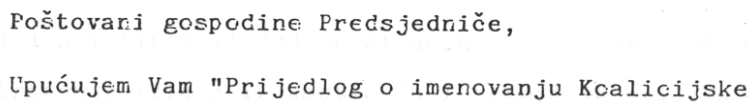
$\log$.

S poštovanjem,

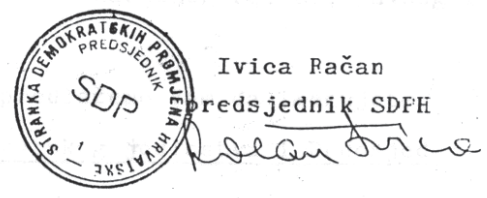

Luor: privetra arhive antoro 
Dr. sc. Mato Arlović: Vlada demokratskog jedinstva koalicijski odgovor na velikosrpsku agresiju Zbornik radova Pravnog fakulteta u Splitu, god. 57, 2/2020, str. 453-478

$\begin{array}{llllllllllllllll}\text { P } & R & I & J & E & D & L & O & G\end{array}$

- imenovanju Koalicijske vlade demokratskcg

jedinstva i Predsjedničkcg vijeća

Ratna razaranja $i$ opće stradanje pripadnika MUP-a i

Narodne garde, kao i civilnog stanovništva, te ratna panika $i$ prateće masovro iseljavanje gradana Republike Hrvatske iz ratcm zahvaćenih gradova i sela prijete općom katastrofcm ne samo Republike već i njenog stanovništva.

Kriza Vlade, izazvana ratnim prilikama, ali i organizacijom vlasti i politikom vladajuće stranke, kao i Vas osobno, nalaže hitno traženje izlaza iz kaotičnih i tragičnih prilika u kojima živimo.

Taj izlaz treba pronaći uz striktno poštivanje:

1. Ustavnih normi - ma kako one ograničavajuće bile - i svih zakorskih normi i zakonskih ustanova, uključujući i ustavni položaj i ulogu Predsjednika Republike,

2. Uvažavanje rezultata prvir slobadnih i demokratskih iztora u Republici Hrvatskoj,

3. Poštivanje svih normi medunarodnog ratnog, javnog i privatnog prava.

Da bi se to ostvarilo, predlažemo Vam da imerujete:

Kcalicijsku vladu demokratskog jedinstva i Predsjed-

ničko vijeće

Sastav, mandat i ovlaštenja (nadležnosti i trajanje

mandata), politička strategija i metode rada vlade trebaju

odražavati formalnj. međustrarački sporazum sviri straraka koje imaju svoje predstavnike u Saboru. 
Nacrt sporazuma mogao bi imati ove elemente:

1. Sve stranke koje potpišu Sporazum u načelu imaju u Vladi rajmanje jedncg predstavnika, koji mcže ili ne mora biti člar dotične stranke, ali svojevoljno mogu taj mandat "ustlipiti" nekoj drugoj strarıci ili predložiti nezavisnog kandidata,

2. Stranačka struktura Vlade u račelu odgovara stranačkoj strukturi Sabora,

3. Trajanje mardata vlace u načelu je jedrako trajanju mandata Sabora, ali je Mandator obvezar prezentirati program Vlade do 8.1istopada 1991. i dugorč̌rii program,

4. Odredivanje Mandatora za sastav Vlade,

5. Ukidanje Krizrıg štaba, Vrhovnog državnog vijeća i Međustranačkog vijeća j imenovanje Predsjedničkog vijeća kao jedinog savjetodavnog vijeća (član 106. Ustava Republike Hrvatske) Predsjednika u kojem su predsjednici ili predstavnici svih saborskil stranaka i nezavisni stručnjaci,

6. Mandatcr za sastav vlace dužan je li roku od 7 dane predložiti Vladiu s detaljnin životopisnim podacima i individualro prilcžerim resorskim programima.

7. Míndator za sastav vlade dužan je u istom roku predložiti Program Vlade - dugorcčni i kratkorcčni,

8. Predstavnici Koalicijske vlade, shodno načelima - djelovanju takvih vlada, imaju pravo veta na ključne cdluke vlade; protokol s popisom tih cdluka bit ćé utaračen kao zaseban dokument. 


\section{Prilog III.}

Sporazum saborskih stranaka o Vladi demokratskog jedinstva potpisan $u$ Zagrebu 2. kolovoza 1991.

"Ratna razaranja i opće stradanje civilnog pučanstva, pripadnika Ministarstva unutarnjih poslova i Narodne garde, te prijeteće masovno iseljavanje građana Republike Hrvatske iz ratom zahvaćenih gradova i sela prijete općom katastrofom ne samo Republike već i njenog pučanstva.

U tim dramatičnim prilikama Republika Hrvatska mora očuvati svoju suverenost, neovisnost, teritorijalnu cjelovitost i demokratski karakter, pa su se čelnici političkih stranaka zastupljenih u Saboru Republike Hrvatske složili sa slijedećim osnovama programa djelovanja Vlade Republike Hrvatske:

1. Organizirati djelotvornu obranu Republike Hrvatske u nametnutom nam ratu i uspostaviti pravni poredak na cijelom njenom području;

2. Zaštititi cjelokupno stanovništvo na ugroženim područjima, bez obzira na nacionalnu pripadnost, osigurati povratak svih izbjeglica u njihova prebivališta, te im pružiti potrebnu pomoć za osiguranje uvjeta normalnog života;

3. Osigurati uvjete za demokratska rješenja problema suživota hrvatskog naroda i dijelova srpskog i drugih naroda koji žive u Republici Hrvatskoj;

4. Osigurati gospodarske uvjete za obranu Republike, unaprjeđujući i tržišno gospodarstvo i privatno vlasništvo;

5. Ubrzati postupak razdruživanja SFRJ;

6. Daljnji razvoj unapređenja demokracije u svim segmentima društva, posebice u funkcioniranju organa vlasti u području javnog informiranja;

7. Uspostaviti djelotvornu suradnju na pronalaženju oblika međusobnih odnosa i veza sa svim republikama i pokrajinama koje priznaju suverenitet Republike Hrvatske, njenu teritorijalnu cjelovitost i legitimitet demokratski izabrane vlasti, te pristaju na konstruktivnu pomoć međunarodne zajednice;

8. Osigurati strogo poštivanje Ustavom utvrđenih ljudskih prava kao i prava manjina na najvišoj europskoj i civilizacijskoj razini, uz interni, a ako je potrebno, i međunarodni nadzor;

9. Vlada će u republičkim, regionalnim i lokalnim tijelima formiranim radi obrane Republike osigurati sudioništvo članova različitih političkih stranaka.

Sporazum su potpisali: Hrvatska demokratska zajednica - dr. Franjo Tuđman (u. z. Ante Beljo); Hrvatska kršćanska demokratska stranka - dr. Ivan Cesar; Hrvatska narodna stranka - dr. Savka Dabčević Kučar; Hrvatska socijalno-liberalna stranka - Dražen Budiša, Hrvatska seljačka stranka - Drago Stipac; Stranka demokratskih promjena - Ivica Račan; Socijaldemokratska stranka-dr. Antun Vujić; Socijalistička stranka Hrvatske - Željko Mažar." ${ }^{51}$

51 Tekst Sporazuma preuzet iz knjige: Vlada demokratskog jedinstva - Istina o Vukovaru $i$ škola demokracije u Hrvatskoj, dr. Franje Gregurića, Školska knjiga, Zagreb, 2017., str. 50-51. 


\section{LITERATURA}

1. Antić, Lj., "Traži li Hrvatska nacionalni konsenzus", članak objavljen 10. siječnja 2013., vidjeti na: www.matica.hr/vijenac/492/trazi-li-hrvatska-nacionalni-konsenzus, posjet stranici 3. listopada 2019.

2. Arlović, M., Pravo nacionalnih manjina u Republici Hrvatskoj, Novi informator, Zagreb, 2015.

3. Bačić, A., Ustavno pravo Republike Hrvatske, Sveučilište Split, Split, 2011.

4. Čular, G., "Vrste stranačke kompeticije i razvoj stranačkog sustava", u Hrvatska politika 1990.-2000., ur. Kasapović, M., Hrvatska politologija, Zagreb, 1992.

5. Čuljak, T., Operacija ŠTIT - treći dio, vidi na: https://novenews.net/hr/znanost/ operacija-stit-treci-dio-48, posjet stranici 2. listopada 2019.

6. Đorđević, J., Politički sistem, Privredni pregled, Beograd, 1973.

7. Gregurić, F., Vlada demokratskog jedinstva - Istina o Vukovaru i škola demokracije u Hrvatskoj, Školska knjiga, Zagreb, 2017.

8. Geršković, L., Suvremeni ustavni problemi, Beograd, 1981.

9. Kasapović, M., Izborni leksikon, Politička kultura, Zagreb, 2003.

10. Kasapović, M., "Demokratska konsolidacija i izborna politika u Hrvatskoj 1990.2000.”, u Hrvatska politika 1990.-2000., ur. Kasapović, M., Hrvatska politologija, Zagreb, 2001.

11. Kasapović, M., ur. Hrvatska politika 1990.-2000., Hrvatska politologija, Zagreb, 2001.

12. Körbler, J., "Da Hrvatska krene naprijed, treba nam velika koalicija", članak u Večernjem listu od 29. srpnja 2019.

13. Manolić, J., Politika i domovina: moja borba za suverenu i socijalnu Hrvatsku, Golden marketing - Tehnička knjiga, Zagreb, 2015.

14. Manjkas, M., Sasvim nepoznati Tuđman, dokumentarni film na https://m.youtube. $\mathrm{com} /$ watch.

15. Notica Velika koalicija i Vlada demokratskog jedinstva na: https://sh.m.wikipedia. org/wiki/Vlada_nacionalnog_jedinstva.

16. Perković Paloš, A., Vlada demokratskog jedinstva, doktorska disertacija, Filozofski fakultet, Split, 2018. na: https://www.bib.irb.hr/992770 [CROSBI], posjet 2. listopada 2019.

17. Politička enciklopedija (notice: "koalicija" i "vlada") Savremena administracija, Beograd, 1975.

18. Račan, I., Otvoreno pismo predsjedniku Republike Hrvatske dr. Franji Tuđmanu od 2. kolovoza 1991.

19. Radin, G., "Vlada demokratskog jedinstva - pogled iz kuta tajnika - 25 godina poslije", u Gregurić, F., Vlada demokratskog jedinstva - Istina o Vukovaru i škola demokracije u Hrvatskoj, Školska knjiga, Zagreb, 2017.

20. Rudolf, D., "Izlaganje na predstavljanju knjige Gregorić, F.; "Vlada demokratskog jedinstva - Istina o Vukovaru i škola demokracije u Hrvatskoj”, dana 22. studenoga 
2017. u Zagrebu, na: https://www.tportal.hr/kultura/clanak/predstavljena-knjigavlada-demokratskog-jedinstva-franje-gregurica-foto-20171110/print; posjet 1 . listopada 2019.

21. Rudolf, D., Stvaranje hrvatske države 1991., Školska knjiga, Zagreb i Književni krug Split, 2017.

22. Tekst Odluke zastupnika Srba koji su napustili Hrvatski sabor i nastavili izvanparlamentarnu političku borbu do ispunjenja njihova zahtjeva, od 31. siječnja 1991., Teleks 163D, privatna arhiva autora.

23. Tomac, Z., Iza zatvorenih vrata, Organizator, Zagreb, 1992.

24. Zakošek, N., "Struktura biračkog tijela i političke promjene u siječanjskim izborima 2000.”, u Hrvatska politika 1990.-2000., zbornik, ur. Kasapović, M., Hrvatska politologija, Zagreb, 2001.

25. Ustav Republike Hrvatske, "Narodne novine" broj 56/1990.

26. Središnji državni portal, Vlada Republike Hrvatske, naslov: „Prethodne vlade“, natuknica u njemu „Treća hrvatska Vlada“, na: https://vlada.gov.hr/prethodnevlade-11348/11348.

27. Središnji državni portal, Vlada Republike Hrvatske, „Treća Vlada RH 17. srpnja 1991. - 12. kolovoza 1992.“, na https://vlada.gov.hr>o-vladi>3-vl...

\section{THE GOVERNMENT OF DEMOCRATIC UNITY COALITION ANSWER TO GREATER SERBIAN AGGRESSION}

This paper deals with political and constitutional legal issues which preceded the establishment of the Government of democratic unity,namely, issues related to the war of aggression against the Republic of Croatia.

Considered are the possible reasons why, for the Government of democratic unity, using in discussions the characteristic that it is a coalition government is avoided even though it is indisputably so according to the way it came about, its authority and very activity. Apart from that, the significance and effects of a government of democratic unity are pointed out with the aim of calming and stabilising the then chaotic political situation in the Republic of Croatia in order to strengthen unity and harmony in the aim of decisivecommitment of the Croatian people in a political sense to establishing an equal community of citizens who will defend the Republic of Croatia and its citizens ensuring freedom, complete territorial integrity and sovereignty. One of the basic aims was international recognition within the borders that Croatia had as the Socialist Republic of Croatia. Previously mentioned issues to be dealt with in this paper will be dealt with primarily from the Constitutional legal aspect as well as from the international law aspect.

Key words: coalition, Government of democratic unity, Homeland War, constitutionality and legality, Serbian aggression, Serbian secessionist policy 